\title{
SVEIN SLETTAN (RED.) FANTASTISK LITTERATUR FOR BARN OG UNGE
}

Bergen: Fagbokforlaget, 2018 (26l s.)

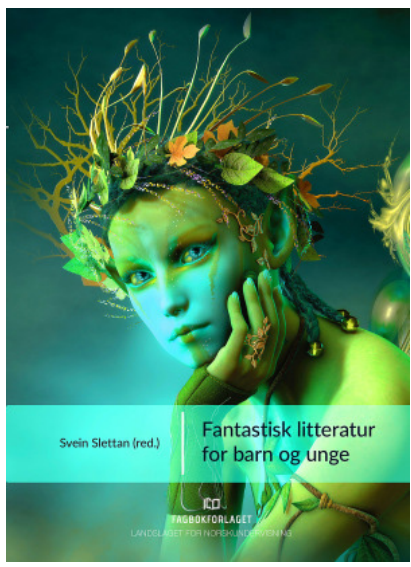

I Fantastisk litteratur for barn og unge (2018) samlar Svein Slettan som redaktör fjorton artiklar om samtida fantastisk litteratur för barn och unga, främst norska så när som på enstaka undantag. Resultatet är en tillgänglig och intresseväckande volym. Att antologiformen i sanning är krävande är välkänt. Hur möter då Slettan detta dilemma? I sin introduktion hävdar han att antologin medvetet hållits öppen för upprepningar och variation. Detta grepp får som följd att en läsare som bekantar sig med verket från pärm till pärm stöter på en rätt omfattande rundgång då delar av fantasyforskningens vid det här laget mycket omfattande definitioner och inriktningar återupprepas. Särskilt förvånande blir detta då samma teoretiska term förekommer i flera olika norska översättningar. Här hade ett stramare redaktörsgrepp ökat läsarvänligheten och dessutom möjliggjort för respektive artikel att borra djupare. Antologin är ändå mycket läsvärd och angelägen i sin breda blick på fantastiken. Att det uttryckligen rör sig om samtida fantastisk litteratur för barn och unga hade gärna fått framgå av antologins titel. Materialet i de olika artiklarna inbegriper såväl bilderböcker, tecknade serier och poesi för barn som äventyrs-, skräck- och djurberättelser. Ett påfallande stråk är inriktningen på ekokritiska läsningar.

I sin introduktion tar Slettan avstamp i fantasyforskningen, med förvånansvärt stor tyngd på 1980-talets ansatser. Den brett upplagda introduktionen strävar efter att vara hyfsat heltäckande och lyckas också säga en hel del, om än själva forskningsunderlaget kunde ha varit mer uppdaterat. Antologin gör inga anspråk på nytänkande, nya inbrytningar eller närkamp med tidigare forskning. Tvärtom är

C2019 Mia Österlund. This is an Open Access article distributed under the terms of the Creative Commons Attribution-Noncommercial 3.0 Unported License (http://creativecommons.org/ licenses/by-nc/3.0/), permitting all non-commercial use, distribution, and reproduction in any medium, provided the original work is properly cited. Citation: Barnboken - tidskrift för barnlitteraturforskning/Barnboken - Journal of Children's Literature Research, Vol. 42,2019 http://dx.doi.
org/10.14811/clr.v42i0.443 
det uppenbart att Slettan med antologin i första hand vill svara mot ett behov att möta den ström av fantasy som utkommer och som också används flitigt i skolvärlden. Något som knyter samman antologin är att merparten av artiklarna motiverar sitt materialurval med att de undersökta böckerna toppar försäljnings- och utlåningsstatistik samt är prisbelönta och omdiskuterade. Boken vänder sig också mycket riktigt till förmedlare, men även till forskare och en intresserad allmänhet.

Att Slettan inleder sin introduktion med ett exempel om en pojkhjälte sticker ut eftersom samtida fantastik så envetet gestaltar flickor som placeras i frälsarroller. Frånvaron av en genusdiskussion ska visa sig vara frapperande i antologin. Detta sammanhänger med en trend i forskningen där många anser att genusvetenskaplig litteraturvetenskap gjort sitt, varför lakuner uppstår i diskussionerna. Redan valet av omslagsbild för antologin väcker frågor. Bilden associerar löst till ekokritisk fantastik som modus genom en älvlik figur med miljöelement som löv och grenar inflätade i håret. Förutom pulsvärmare är flickan på bilden naken. Bilden signalerar att samtida fantastik upprätthåller sig vid hur flickskap materialiseras i barn- och ungdomsböcker, men vid en djupdykning i antologins texter blir frånvaron av genusperspektiv alltså uppenbar. Trots sin fantasyanstrykning är omslagsbilden inte heller knuten till ett skönlitterärt verk, utan tvärtom en royaltyfri bild från en enorm nätdomän.

För en läsare som saknar breda kunskaper i fantasyforskning erbjuder antologin dock en hel del, och den stora behållningen är självfallet att teorierna används på ett samtidsmaterial som inte tidigare utforskats i någon nämnvärd utsträckning. Det breda och inkluderande greppet borgar för en viss dynamik. Boken delas in i fyra huvudavdelningar: fabeltraditionen med djurberättelser och nonsens, magiska världar, det fantastiska i det realistiska samt fantastik, skola och förmedling.

Boken är illustrerad med färgstarka bilder vilket förhöjer läsupplevelsen. Därför är det också roligt och givande att de två inledande analyserna, av Anne Skaret och Anita Berge Heivoll, granskar fantastik i bilderboken. Skaret tar sig an kulturmöten i bilderboken Fremmed (2010) av Kaia, Bendik och Trond Brænne illustrerad av Per Dybvig, där hon visar på hur antropomorfa djurkaraktärer inordnas i fantastik i den barnlitterära traditionen. Diskussionen om tecknarstil öppnar upp mot satirens och humorns domäner och hade gärna fått fortsätta. Kanske hade det också varit på sin plats med en metareflektion om vad som händer då materialet så uppenbart adresserar den tematik som undersöks. Heivoll å sin sida granskar 
barnlyrik av Gro Dahle bildberättad av Kaia Dahle Nyhus i ljuset av barnperspektiv, nonsenstradition och karnevalism. Dessa studier pekar på fantastikbegreppets tänjbarhet och är i sig ögonöppnande. Att dessutom Siri Odfjell Risdal tar sig an fantasy i form av tecknade serier är välkommet. Hon visar föredömligt pedagogiskt på hur materialets appellstrukturer som tempo, karaktärer, ton, bakgrund, händelseförlopp och språk sätts i spel.

Nordisk fantastik förhåller sig självfallet till nordisk mytologi och nordiska väsen förekommer gärna i romanerna. Detta tar Lars Rune Waage fasta på då han läser Alexander Løkens trilogi om Edvard Frost (2014-2016) som en vandring genom protagonistens psyke. Särskilt gränsdragningen mellan troll och människa som är påtaglig i nordisk kultur diskuteras och knyts till teorier om det monstruösa.

Nina Goga som driver ett större ekokritiskt forskningsprojekt tar sig an svenska Frida Nilssons Ishavspirater (2015) och läser den som ekokritisk. Särskilt övertygande använder Goga sig av ett av sina angränsande forskningsområden, nämligen det om kartors roll i barnlitteraturen. Hon visar på hur kartorna hos Nilsson främst fungerar som förstärkare av fantastiken. Gogas artikel är samtidigt ett exempel på hur genusdiskussionen skjuts i bakgrunden trots att den undersökta romanen så kraftigt deltar i en trend, men är i övrigt exemplariskt välstrukturerad och angelägen.

Lykke Guanio-Uluru tar sig an den posthumana teorin i mötet med Bobbie Peers Luridiumstyven (2015) - utgiven på svenska med titeln Luridiumtjuven - som läses som sci-fi interfolierad med gotik och fantastik där vetenskap och irrationalitet konfronteras. Med avstamp i Victoria Flanagans tes om en utveckling inom barnlitteratur från teknofobi till teknopositivism för Guanio-Uluru en genrediskussion och pekar på hur sci-fitroper och posthuman tematik flätas samman med element från gotik. Artikeln är högaktuell och svarar mot ett behov av läsningar av denna litteraturtyp.

En del av bidragen gapar efter för mycket och blir i förlängningen för svepande. Detta gäller bland annat Fridunn Tørå Karsruds breda översikt om matens roll i myt, saga och fantasy. Istället för att borra djupt i ett samtida aktuellt exempel sveper artikeln dessvärre över mycket som redan är välkänt. Detta vittnar redan de talrika underrubrikerna om.

Inte oväntat diskuteras Siri Pettersens romaner i hela två artiklar. Åsmund Hennigs analys av trilogin Odinsbarn (2013-2015) blottlägger romanens undersökning av gränsen mellan mänskligt och omänskligt i ljuset av mångkulturalitet, men är dessvärre helt renons på genusperspektiv. Detta är ett exempel på hur valet av ett snävt 
perspektiv, här mångkulturalitet, helt skymmer för romansviten väsentliga förutsättningar. Det finns en rikedom av forskning som lyfter genusperspektivet i fantasy, inte minst då det gäller samtida flickskildringars revolutionärer som här sätts under lupp. Samma snäva förhållningssätt präglar Aasta Marie Bjorvand Bjørkøys och Cecilie Takles läsning av Pettersens roman Bobla (2017) - på svenska utgiven med titeln Bubblan - där en linje från självmedvetenhet till ekomedvetenhet aviseras, men där artikeln inte använder sig av ekokritisk barnlitteraturforskning i någon större utsträckning.

Mycket av samtidsfantastiken återupprepar tidigare inbrytningar, vilket gör det svårt att hävda att något verkligen är nyskapande. Denna risk för att utropa nya grepp lyckas antologin parera. Ansatsen att samla forskning kring ny norsk barnlitteratur är mer än välkommen och bjuder på initierade och intresseväckande läsningar. I sin helhet är Fantastisk litteratur for barn og unge ett fräscht tillskott till den nordiska barnlitteraturforskningen.

Mia Österlund

Docent i litteraturvetenskap

Åbo Akademi 